\title{
Protein and Oil Contents of Several Soybean Genotypes under Normal and Drought Stress Environments at Reproductive Stage
}

\author{
Ayda Krisnawati*, M. Muchlish Adie \\ Indonesian Legumes and Tuber Crops Research Institute, Jl. Raya Kendalpayak KM 8, P0 Box 66 Malang, \\ Indonesia. \\ * Corresponding author. Tel.: +62341801468; email: my_ayda@yahoo.com \\ Manuscript submitted February 3, 2017; accepted February 20, 2017. \\ doi: 10.17706/ijbbb.2017.7.4.252-261
}

\begin{abstract}
Soybean (Glycine max L.) is one of the world's most important sources of high quality proteins and vegetable oils. In Indonesia, soybean is mostly cultivated in dry season, hence prone to the drought stress. Protein and oil content of 19 soybean genotypes were evaluated based on field research which was conducted in dry season (May - August 2015) in Probolinggo, Indonesia. The experiment was carried out in two environments, namely normal environment (plant was irrigated during the growth period), and drought environment (plant was irrigated only up to 40 days after planting). The results showed that variation in protein and oil contents depends on the genotype. Protein content was less sensitive to drought stress at reproductive stage, by an average decrease of $0.59 \%$, whereas the decrease of oil content reached $2.82 \%$. The protein contents of twelve genotypes decreased in normal to stressed environments, from 0.39 to $5.31 \%$; and seven genotypes increased in stressed environments with a range of 0.28 to $7.05 \%$. A similar pattern was shown in oil contents, with a range of decrease from 0.88 to $21.68 \%$ in twelve genotypes, and an increase from 0.37 to $5.57 \%$ in seven genotypes. Genotype of G511H/Anjs/Anjs///Anjs-3-3 showed a highest consistency of protein content in both of normal and stressed environments, i.e. $42.44 \%$ and 42.19\%, respectively. Soybean G511H/Anjs/Anjs-5-5 had high oil content $(19.71 \%$ and $20.08 \%$ in the optimal and drought environments, respectively) as well as G511 H/Anj//Anj///Anj////Anjs-6-8 (20.18\% and $19.43 \%$ in the optimal and drought environments, respectively). Those genotypes identified as early maturing ( $<80$ days) and large seeded-size ( $>14 \mathrm{~g} / 100$ seeds), but with a relatively low yield. Hence, it is recommended to use as gene sources for improvement of oil and protein contents within soybean breeding program in Indonesia.
\end{abstract}

Key words: Drought stress, Glycine max, oil, protein, reproductive stage.

\section{Introduction}

In Indonesia, soybean is the third most important food crops after rice and maize. Indonesian soybean demand in 2017 is estimated to reach 2,380,872 tons. Most of soybeans are processed for industrial raw material, for the production of tempeh and tofu. In tropical country, such as Indonesia, soybean can be grown three times a year, and mostly cultivated in the dry season (June/July - September/October) thus susceptible to drought stress when the plants at reproductive stage.

Water deficit and drought stress negatively affected the physiological and biochemical process of the plants. Drought stress at reproductive stage reduced the soybean yield from 40 to $68 \%$ [1], [2], depends on 
the magnitude of the stress, growth stage at which drought occur, and the susceptibility of variety [2]-[4]. Among other legume species, soybean seeds contain the highest amount of protein and a relatively high level of oil [5].

The effect of drought stress on the consistency of oil and protein was varied. A study by [6] reported that oil and protein content in soybean seeds was quantitative trait which was controlled by genes as well as the environments. This shows that besides being controlled by genetic factors, the consistency of protein and oil content was also potentially influenced by the environment. Study of the relationship between the temperature of the protein and oil content was carried out by [7], and they stated that the oil content in soybeans increases with increasing temperature of $14^{\circ} \mathrm{C}$ to $28^{\circ} \mathrm{C}$, and there was no consistent pattern related to protein.

The nutritional composition on soybean seed varies between cultivars, and is determined by the time of planting and environmental factors [8]. A relationship between the protein content and seed yield in soybeans was relatively small, and its contribution to the seed yield was more determined by the isoflavones content. Furthermore, a negatively significant correlation was reported between oil content with protein content [9]. However, a study by [6] showed insignificant interaction between locations with cultivar in terms of protein content. A study has been conducted by [10] about the change in the soybean agronomic characters at full and deficit irrigation under sub-humid climate conditions. They obtained that the oil content decreased from optimal conditions by $22.7 \%$ to $19.1 \%$ in water deficit conditions, whereas the protein content increased from $30.5 \%$ (optimal) to $33.6 \%$ (water deficit). Another study by [11] showed that there was an interaction between cultivar with drought in oil content, but not found for protein content. The inconsistency of the various results of those studies indicate the roles of genes and environment, especially photoperiod, drought, or highly temperature during seed filling, which will affect the performance of protein and oil on the drought-stressed environment.

The objective of the experiment was to identify the consistency of the protein and oil content form several soybean genotypes under normal and drought stress environment at tropical area.

\section{Material and Method}

The field experiment was carried out in dry land at Probolinggo, Indonesia (at altitude $20 \mathrm{~m}$ above sea level, D2 climate type based on Oldeman system, and soil type of Alfisol) during the dry season (May to August 2015). The experimental design was randomized block design with two different environments, i.e. (1) normal/optimal environment (0) consisting of irrigated during the growth period, and (2) drought environment (D) consisting of irrigated only up to 40 days after planting. The sample trait consisted of 19 soybean genotypes, and each genotype had four replications. Each genotype was planted in $1.2 \mathrm{~m}$ x $4.5 \mathrm{~m}$ plot size, two plants per hill. Fertilizer of $250 \mathrm{~kg}$ Phonska/ha with the addition of $100 \mathrm{~kg}$ SP 36 was applied after sowing the seeds. Plant maintenance was conducted including irrigation, optimal control of pest and disease and intensive weeding. Soil moisture in the normal and drought environment was measured with five days interval until 75 days after planting (DAP), respectively. Soil sample was taken at five points diagonally. Data were collected on protein content (\%), oil content (\%), days to maturity (days), 100 seed weight ( $\mathrm{g}$ ), and seed yield ( $\mathrm{t} / \mathrm{ha}$ ).

\section{Result}

\subsection{Soil Moisture}

Rainfall during the study from May to August 2015 was in relatively small amount. In May, the rainfall amounted to $103 \mathrm{~mm}$ with the number of rainy days of 7 times. In June, the rainfall amounted to $13 \mathrm{~mm}$ with rainy days as much as two times, in July as much as $12 \mathrm{~mm}$ with a 3 times of rainy days, and no rain in 
August. This showed that the research took place in dry conditions even when the plants were in the reproductive stage.

The soil moisture from 40 to 75 days after sowing was presented in Table 1 and Fig. 1. The irrigation was stopped at 40 DAP. The drought stress was started from 60 DAP, which showed by the decrease soil moisture at drought environment. At 60 days after planting (dap), the soil moisture has decreased 29.13\% from the optimal to stress condition, and became $47.61 \%$ at 75 DAP. Based on those results, it can be seen that the research was in drought condition, even no rain at reproductive stage.

The combined analysis of variance for protein content, oil content, days to maturity, 100 seed weight, and seed yield was presented in Table 2. All parameters were significantly different between genotypes. Meanwhile, environment (E) and genotype $\times$ environment interaction (GEI) were significant for all parameter, except for days to maturity. The CV value ranged from $1.17 \%$ to $17.06 \%$.

Table 1. Soil Moisture Level at Normal and Stress Environments 2015

\begin{tabular}{llll}
\hline \hline \multirow{2}{*}{$\begin{array}{l}\text { Plant age } \\
\text { dap) }\end{array}$} & \multicolumn{3}{l}{ Soil moisture (\%) } \\
\cline { 2 - 4 } & Optimal & Drought & O-D (\%) \\
\hline 40 & 23.14 & 23.88 & -3.20 \\
45 & 31.64 & 31.94 & -0.95 \\
50 & 26.71 & 26.76 & -0.19 \\
55 & 21.74 & 23.42 & -7.73 \\
60 & 30.69 & 21.75 & 29.13 \\
65 & 26.61 & 20.58 & 22.66 \\
70 & 22.02 & 15.23 & 30.84 \\
75 & 43.50 & 22.79 & 47.61 \\
\hline Mean & 28.26 & 23.29 & 14.77 \\
\hline \hline
\end{tabular}

$\mathrm{O}=$ optimal environment, $\mathrm{D}=$ drought environment

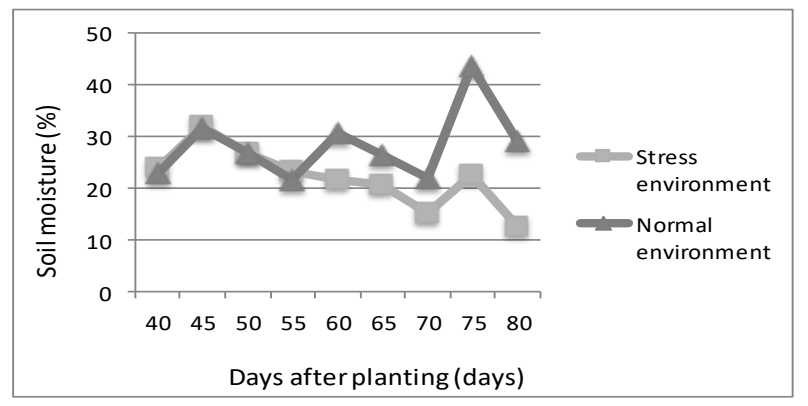

Fig. 1. Soil moisture level at optimal and drought environments.

Table 2. Combined Analysis of Variance for Protein Content, Oil Content, Days to Maturity, 100 Seed Weight, and Seed Yield 2015

\begin{tabular}{lllll}
\hline \hline \multirow{2}{*}{ Characters } & \multicolumn{3}{c}{ Mean square } & CV (\%) \\
\cline { 2 - 4 } & Environment (E) & Genotype (G) & $\mathrm{G} \times \mathrm{E}$ & \\
\hline Protein content (dry basis) \% & $1.0282^{*}$ & $9.9237^{* *}$ & $1.4128^{* *}$ & 1.17 \\
Oil content (dry basis) \% & $5.2474^{* *}$ & $2.2490^{* *}$ & $1.6108^{* *}$ & 3.25 \\
Days to maturity (days) & $1095.1578 \mathrm{~ns}$ & $18.3552^{* *}$ & $1.7412 \mathrm{~ns}$ & 3.75 \\
100 seed weight (g) & $295.9353^{* *}$ & $70.9993^{* *}$ & $1.9821^{* *}$ & 4.93 \\
Seed yield (t/ha) & $9.9758^{* *}$ & $1.1925^{* *}$ & $0.3023^{* *}$ & 17.06 \\
\hline
\end{tabular}

** = significant at $1 \%$ probability level $(p<0.01),{ }^{*}=$ significant at $5 \%$ probability level $(p<0.05), n s=$ not significant, $C V=$ coefficient of variation 


\subsection{Protein Content}

Protein content of 19 soybean genotypes under optimal environment ranging from $36.98 \%$ to $42.44 \%$ (dry basis) with an average of 39.52\%. Protein content under drought environment ranging from $35.06-$ $42.19 \%$ (dry basis) with an average of $39.29 \%$ (Table 3). The environmental changes from optimal to drought caused decreased level of protein by $0.59 \%$.

Each soybean genotype showed different response to the protein changes at different environment. Most of genotypes (12 genotypes) showed decreased protein content between $0.39-5.31 \%$, which caused by drought stress. An increase protein content under drought environment was showed by seven genotypes, which was ranging from $0.28-3.62 \%$. In this study, one genotype (G511H/Anjs/Anjs///Anjs-3-3) had high protein content under both of optimal and drought environment, i.e. $42.44 \%$ and $42.19 \%$, respectively. This genotype also showed a consistency of protein content under drought environment.

Table 3. Protein Content of 19 Soybean Genotypes under Optimal and Drought Environments 2015

\begin{tabular}{|c|c|c|c|c|c|}
\hline \multirow[t]{2}{*}{ No } & \multirow[t]{2}{*}{ Genotype } & \multicolumn{2}{|c|}{$\begin{array}{l}\text { Protein content } \\
\qquad \% \mathrm{db})\end{array}$} & \multirow{2}{*}{$\begin{array}{l}\text { Average } \\
(\%)\end{array}$} & \multirow{2}{*}{$\begin{array}{l}\text { Decline } \\
\text { O to D } \\
(\%)\end{array}$} \\
\hline & & 0 & $\mathrm{D}$ & & \\
\hline 1 & G 511 H/Anjs/Anjs-2-13 & 40.70 & 40.54 & 40.62 & 0.39 \\
\hline 2 & G 511 H/Anjs-1-1 & 39.57 & 40.53 & 40.05 & -2.43 \\
\hline 3 & G $511 \mathrm{H} / \operatorname{Arg} / / \operatorname{Arg} / / / \operatorname{Arg}-30-7$ & 40.91 & 39.86 & 40.38 & 2.57 \\
\hline 4 & G 511 H/Kaba//Kaba///-4-4 & 37.93 & 37.68 & 37.80 & 0.66 \\
\hline 5 & G 511 H/Kaba//Kaba///Kaba////Kaba 16-2 & 36.98 & 35.06 & 36.02 & 5.19 \\
\hline 6 & G 511 H/Anjs/Anjs///Anjs-3-3 & 42.44 & 42.19 & 42.31 & 0.60 \\
\hline 7 & G 511 H/Anjs/Anjs///Anjs-6-13 & 37.96 & 38.11 & 38.03 & -0.41 \\
\hline 8 & G 511 H/Anjs/Anjs-1-2 & 39.09 & 41.85 & 40.47 & -7.05 \\
\hline 9 & G 511 H/Anjs/Anjs-5-5 & 38.91 & 36.85 & 37.88 & 5.31 \\
\hline 10 & G 511 H/Anjs/Anjs///Anjs-6-11 & 39.50 & 40.93 & 40.22 & -3.62 \\
\hline 11 & G 511 H/Anjs/Anjs///Anjs-8-1 & 39.34 & 39.45 & 39.39 & -0.28 \\
\hline 12 & G 511 H/Anjs/Anjs-1-3 & 39.70 & 39.91 & 39.80 & -0.54 \\
\hline 13 & G 511 H/Anjs/Anjs///Anjs-6-12 & 40.89 & 40.41 & 40.65 & 1.19 \\
\hline 14 & G 511 H/Anj//Anj///Anj////Anjs-6-8 & 39.14 & 38.10 & 38.62 & 2.66 \\
\hline 15 & Anjasmoro & 40.72 & 41.22 & 40.97 & -1.22 \\
\hline 16 & Grobogan & 39.90 & 39.28 & 39.59 & 1.55 \\
\hline 17 & Dena 1 & 38.44 & 36.78 & 37.61 & 4.32 \\
\hline 18 & Wilis & 38.30 & 37.78 & 38.04 & 1.36 \\
\hline \multirow[t]{2}{*}{19} & Detam 4 & 40.54 & 40.03 & 40.28 & 1.27 \\
\hline & Average & 39.52 & 39.29 & 39.41 & 0.59 \\
\hline
\end{tabular}

$\mathrm{O}=$ optimal environment, $\mathrm{D}=$ drought environment, $\mathrm{db}=$ dry basis

\subsection{Oil Content}

Oil content of 19 soybean genotypes were varied. The range of oil content under optimal environment was between $17.34-22.15 \%$ (dry basis) with an average of $18.64 \%$, while under drought environment ranging from $17.35 \%$ to $20.08 \%$ (dry basis) with an average of $18.11 \%$ (Table 4 ). The range of the lowest oil content between two environments was similar, but the highest range value had a considerable difference.

The decreased oil content from optimal to drought environment was $2.82 \%$, higher than those of the decrease protein content $(0.59 \%)$. The soybean response to drought stress was varied among genotypes. Based on the results, a total of seven genotypes had increase in oil content under drought, ranging from 0.37 to $5.57 \%$. Meanwhile, other 12 genotypes had decrease in oil content between 0.11 to $21.68 \%$. In this 
study, we also identify a genotype (G511H/Kaba//Kaba///Kaba////Kaba 16-2) categorized as susceptible to drought, which showed by the rate of oil content decline by $21.68 \%$. On the contrary, G511H/Anjs/Anjs-5-5 and G511H/Anj//Anj///Anj////Anjs-6-8 had high oil content and also showed a stability under both different environments.

Table 4. Oil Content of 19 Soybean Genotypes under Optimal and Drought Environments 2015

\begin{tabular}{|c|c|c|c|c|c|}
\hline \multirow[t]{2}{*}{ No } & \multirow[t]{2}{*}{ Genotype } & \multicolumn{2}{|c|}{$\begin{array}{l}\text { Oil content } \\
\text { (\% db) }\end{array}$} & \multirow[t]{2}{*}{$\begin{array}{l}\text { Average } \\
(\%)\end{array}$} & \multirow{2}{*}{$\begin{array}{l}\text { Decline } \\
\text { O to D } \\
(\%)\end{array}$} \\
\hline & & 0 & $\mathrm{D}$ & & \\
\hline 1 & G 511 H/Anjs/Anjs-2-13 & 17.34 & 18.31 & 17.82 & -5.57 \\
\hline 2 & G 511 H/Anjs-1-1 & 18.75 & 17.37 & 18.06 & 7.34 \\
\hline 3 & G 511 H/Arg//Arg///Arg-30-7 & 17.91 & 18.25 & 18.08 & -1.90 \\
\hline 4 & G 511 H/Kaba//Kaba///-4-4 & 19.17 & 17.93 & 18.55 & 6.49 \\
\hline 5 & G 511 H/Kaba//Kaba///Kaba////Kaba 16-2 & 22.15 & 17.35 & 19.75 & 21.68 \\
\hline 6 & G 511 H/Anjs/Anjs///Anjs-3-3 & 17.46 & 17.99 & 17.72 & -3.07 \\
\hline 7 & G 511 H/Anjs/Anjs///Anjs-6-13 & 19.84 & 18.29 & 19.06 & 7.79 \\
\hline 8 & G 511 H/Anjs/Anjs-1-2 & 18.18 & 17.75 & 17.97 & 2.37 \\
\hline 9 & G 511 H/Anjs/Anjs-5-5 & 19.71 & 20.08 & 19.89 & -1.88 \\
\hline 10 & G 511 H/Anjs/Anjs///Anjs-6-11 & 17.36 & 17.84 & 17.60 & -2.77 \\
\hline 11 & G 511 H/Anjs/Anjs///Anjs-8-1 & 18.93 & 17.84 & 18.38 & 5.76 \\
\hline 12 & G 511 H/Anjs/Anjs-1-3 & 17.92 & 17.90 & 17.91 & 0.11 \\
\hline 13 & G 511 H/Anjs/Anjs///Anjs-6-12 & 17.39 & 17.45 & 17.42 & -0.37 \\
\hline 14 & G 511 H/Anj//Anj///Anj////Anjs-6-8 & 20.18 & 19.43 & 19.80 & 3.69 \\
\hline 15 & Anjasmoro & 18.39 & 17.47 & 17.93 & 5.00 \\
\hline 16 & Grobogan & 17.64 & 18.21 & 17.92 & -3.26 \\
\hline 17 & Dena 1 & 18.35 & 18.03 & 18.19 & 1.74 \\
\hline 18 & Wilis & 18.83 & 18.66 & 18.74 & 0.88 \\
\hline \multirow[t]{2}{*}{19} & Detam 4 & 18.69 & 18.03 & 18.36 & 3.53 \\
\hline & Average & 18.64 & 18.11 & 18.38 & 2.82 \\
\hline
\end{tabular}

$\mathrm{O}=$ optimal environment, $\mathrm{D}=$ drought environment, $\mathrm{db}=$ dry basis

\subsection{Agronomic Characters}

The primary agronomic characters of soybean in tropical areas, such as Indonesia, consisted of seed yield, days to maturity, and seed size. Seed yield is directly related to total protein and oil content in soybean seed. In Indonesia, soybean is cultivated three times a year, thus the early days to maturity ( $<80$ days) is an important character. Seed size is related to the use of soybean as processed soy food ingredients, especially for tempeh which require large seed size (>14 g/100 seeds).

Under optimal environment, seed yield of 19 soybean genotypes ranging from $1.64-3.41 \mathrm{t} / \mathrm{ha}$ (in average of $2.43 \mathrm{t} / \mathrm{ha}$ ) and under drought environment ranging from $1.50-2.45 \mathrm{t} / \mathrm{ha}$ (in average of 1.92 t/ha). In this study, the decrease in seed yield from optimal to drought environment was only $20.99 \%$ (Table 5), revealed that most of soybean genotypes were relatively tolerant to drought stress. Based on the results, two genotypes could produce over $3.30 \mathrm{t} / \mathrm{ha}$, but relatively less tolerant to drought which showed a decrease in yield over $30 \%$. In this study, Wilis variety also identified as tolerant to drought showed by yield reduction around $10.58 \%$.

Seed size, as measured by 100 seed weight, ranged from $11.77-23.77 \mathrm{~g} / 100$ seeds (in average of 17.42 $\mathrm{g} / 100$ seeds) under optimal environment, and 10.30 - $22.77 \mathrm{~g} / 100$ seeds (in average of $16.03 \mathrm{~g} / 100$ seeds) under drought environment (Table 6). Category of large seed size in Indonesia is when the 100 seed weight 
more than $14 \mathrm{~g} / 100$ seeds, thus most the tested genotypes categorized as large seed size. The decrease in seed size cause by drought was $16.02 \%$.

The days to maturity of 19 soybean genotypes under optimal environment ranging from 73 - 82 days (in average of 78 days), and under drought environment ranging from 70 - 76 days (in average of 73 days) (Table 7). Drought condition accelerate the maturation period by five days.

Table 5. Seed Yield of 19 Soybean Genotypes under Optimal and Drought Environments 2015

\begin{tabular}{|c|c|c|c|c|c|}
\hline \multirow[t]{2}{*}{ No } & \multirow[t]{2}{*}{ Genotype } & \multicolumn{2}{|c|}{$\begin{array}{l}\text { Seed yield } \\
\qquad(\mathrm{t} / \mathrm{h})\end{array}$} & \multirow[t]{2}{*}{$\begin{array}{l}\text { Average } \\
\text { (t/ha) }\end{array}$} & \multirow[t]{2}{*}{$\begin{array}{l}\text { Decline } \\
\text { O to D } \\
(\%)\end{array}$} \\
\hline & & 0 & $\mathrm{D}$ & & \\
\hline 1 & G 511 H/Anjs/Anjs-2-13 & 2.47 & 2.19 & 2.33 & 11.34 \\
\hline 2 & G 511 H/Anjs-1-1 & 1.97 & 1.86 & 1.92 & 5.58 \\
\hline 3 & G 511 H/Arg//Arg///Arg-30-7 & 2.54 & 2.08 & 2.31 & 18.11 \\
\hline 4 & G 511 H/Kaba//Kaba///-4-4 & 2.59 & 1.16 & 1.88 & 55.21 \\
\hline 5 & G 511 H/Kaba//Kaba///Kaba////Kaba 16-2 & 1.79 & 1.26 & 1.53 & 29.61 \\
\hline 6 & G 511 H/Anjs/Anjs///Anjs-3-3 & 2.07 & 1.97 & 2.02 & 4.83 \\
\hline 7 & G 511 H/Anjs/Anjs///Anjs-6-13 & 2.73 & 1.98 & 2.36 & 27.47 \\
\hline 8 & G 511 H/Anjs/Anjs-1-2 & 3.31 & 2.17 & 2.74 & 34.44 \\
\hline 9 & G 511 H/Anjs/Anjs-5-5 & 1.70 & 1.45 & 1.58 & 14.71 \\
\hline 10 & G 511 H/Anjs/Anjs///Anjs-6-11 & 2.51 & 2.27 & 2.39 & 9.56 \\
\hline 11 & G 511 H/Anjs/Anjs///Anjs-8-1 & 1.98 & 1.62 & 1.80 & 18.18 \\
\hline 12 & G 511 H/Anjs/Anjs-1-3 & 1.64 & 1.50 & 1.57 & 8.54 \\
\hline 13 & G 511 H/Anjs/Anjs///Anjs-6-12 & 2.61 & 2.04 & 2.33 & 21.84 \\
\hline 14 & G 511 H/Anj//Anj///Anj////Anjs-6-8 & 2.31 & 1.93 & 2.12 & 16.45 \\
\hline 15 & Anjasmoro & 2.76 & 1.84 & 2.30 & 33.33 \\
\hline 16 & Grobogan & 2.26 & 2.15 & 2.21 & 4.87 \\
\hline 17 & Dena 1 & 3.41 & 2.33 & 2.87 & 31.67 \\
\hline 18 & Wilis & 2.74 & 2.45 & 2.60 & 10.58 \\
\hline \multirow[t]{2}{*}{19} & Detam 4 & 2.73 & 2.16 & 2.45 & 20.88 \\
\hline & Average & 2.43 & 1.92 & 2.18 & 20.99 \\
\hline
\end{tabular}

$\mathrm{O}=$ optimal environment, $\mathrm{D}=$ drought environment

Table 6.100 Seed Weight of 19 Soybean Genotypes under Optimal and Drought Environments 2015

\begin{tabular}{|c|c|c|c|c|c|}
\hline \multirow[t]{2}{*}{ No } & \multirow[t]{2}{*}{ Genotype } & \multicolumn{2}{|c|}{100 seed weight $(\mathrm{g})$} & \multirow{2}{*}{$\begin{array}{l}\text { Average } \\
\text { (g) }\end{array}$} & \multirow{2}{*}{$\begin{array}{l}\text { Decline } \\
\text { O to D (\%) }\end{array}$} \\
\hline & & 0 & $\mathrm{D}$ & & \\
\hline 1 & G 511 H/Anjs/Anjs-2-13 & 21.09 & 18.34 & 19.72 & 13.02 \\
\hline 2 & G 511 H/Anjs-1-1 & 19.15 & 15.89 & 17.52 & 17.06 \\
\hline 3 & G 511 H/Arg//Arg///Arg-30-7 & 17.60 & 15.05 & 16.33 & 14.46 \\
\hline 4 & G $511 \mathrm{H} / \mathrm{Kaba} / / \mathrm{Kaba} / / /-4-4$ & 17.93 & 12.67 & 15.30 & 29.35 \\
\hline 5 & G 511 H/Kaba//Kaba///Kaba////Kaba 16-2 & 18.35 & 16.44 & 17.39 & 10.45 \\
\hline 6 & G 511 H/Anjs/Anjs///Anjs-3-3 & 18.45 & 17.18 & 17.82 & 6.88 \\
\hline 7 & G 511 H/Anjs/Anjs///Anjs-6-13 & 16.70 & 13.47 & 15.08 & 19.33 \\
\hline 8 & G 511 H/Anjs/Anjs-1-2 & 17.41 & 14.18 & 15.80 & 18.53 \\
\hline 9 & G 511 H/Anjs/Anjs-5-5 & 17.43 & 15.57 & 16.50 & 10.68 \\
\hline 10 & G 511 H/Anjs/Anjs///Anjs-6-11 & 19.01 & 15.38 & 17.19 & 19.11 \\
\hline 11 & G 511 H/Anjs/Anjs///Anjs-8-1 & 17.45 & 14.93 & 16.19 & 14.44 \\
\hline 12 & G 511 H/Anjs/Anjs-1-3 & 17.84 & 15.27 & 16.56 & 14.39 \\
\hline 13 & G 511 H/Anjs/Anjs///Anjs-6-12 & 18.16 & 14.79 & 16.48 & 18.54 \\
\hline
\end{tabular}




\begin{tabular}{llllll}
14 & G511 H/Anj//Anj///Anj////Anjs-6-8 & 16.72 & 13.45 & 15.09 & 19.58 \\
15 & Anjasmoro & 17.54 & 14.27 & 15.91 & 18.63 \\
16 & Grobogan & 23.77 & 22.77 & 23.27 & 4.21 \\
17 & Dena 1 & 12.33 & 9.03 & 10.68 & 26.76 \\
18 & Wilis & 12.36 & 9.05 & 10.70 & 26.77 \\
19 & Detam 4 & 11.77 & 10.30 & 11.03 & 12.43 \\
\hline & Average & 17.42 & 14.63 & 16.03 & 16.02 \\
\hline \hline
\end{tabular}

O = optimal environment, $\mathrm{D}=$ drought environment

Table 7. Days to Maturity of 19 Soybean Genotypes under Optimal and Drought Environments 2015

\begin{tabular}{|c|c|c|c|c|c|}
\hline \multirow[t]{2}{*}{ No } & \multirow[t]{2}{*}{ Genotype } & \multicolumn{2}{|c|}{$\begin{array}{l}\text { Days to maturity } \\
\text { (days) }\end{array}$} & \multirow{2}{*}{$\begin{array}{l}\text { Average } \\
\text { (days) }\end{array}$} & \multirow{2}{*}{$\begin{array}{l}\text { Decline } \\
\text { O to D (\%) }\end{array}$} \\
\hline & & 0 & $\mathrm{D}$ & & \\
\hline 1 & G 511 H/Anjs/Anjs-2-13 & 77 & 71 & 74 & 7.47 \\
\hline 2 & G 511 H/Anjs-1-1 & 78 & 74 & 76 & 4.82 \\
\hline 3 & G 511 H/Arg//Arg///Arg-30-7 & 78 & 72 & 75 & 7.07 \\
\hline 4 & G $511 \mathrm{H} / \mathrm{Kaba} / / \mathrm{Kaba} / / /-4-4$ & 83 & 76 & 79 & 8.48 \\
\hline 5 & G 511 H/Kaba//Kaba///Kaba////Kaba 16-2 & 82 & 78 & 80 & 4.91 \\
\hline 6 & G 511 H/Anjs/Anjs///Anjs-3-3 & 74 & 70 & 72 & 5.76 \\
\hline 7 & G 511 H/Anjs/Anjs///Anjs-6-13 & 77 & 72 & 75 & 6.49 \\
\hline 8 & G 511 H/Anjs/Anjs-1-2 & 81 & 76 & 78 & 5.88 \\
\hline 9 & G 511 H/Anjs/Anjs-5-5 & 80 & 73 & 76 & 8.46 \\
\hline 10 & G 511 H/Anjs/Anjs///Anjs-6-11 & 74 & 70 & 72 & 5.74 \\
\hline 11 & G 511 H/Anjs/Anjs///Anjs-8-1 & 79 & 72 & 76 & 8.86 \\
\hline 12 & G 511 H/Anjs/Anjs-1-3 & 79 & 72 & 75 & 8.89 \\
\hline 13 & G 511 H/Anjs/Anjs///Anjs-6-12 & 80 & 73 & 77 & 8.15 \\
\hline 14 & G 511 H/Anj//Anj///Anj////Anjs-6-8 & 79 & 71 & 75 & 10.09 \\
\hline 15 & Anjasmoro & 79 & 76 & 78 & 3.48 \\
\hline 16 & Grobogan & 73 & 70 & 72 & 4.44 \\
\hline 17 & Dena 1 & 80 & 76 & 78 & 4.72 \\
\hline 18 & Wilis & 82 & 76 & 79 & 7.60 \\
\hline \multirow[t]{2}{*}{19} & Detam 4 & 77 & 71 & 74 & 8.41 \\
\hline & Average & 78 & 73 & 76 & 6.85 \\
\hline
\end{tabular}

$\mathrm{O}=$ optimal environment, $\mathrm{D}=$ drought environment

\section{Discussion}

Soybeans are an excellent source of plant-based protein, and also source of vegetable oil. In Indonesia, most soybeans are used as food processing products, especially tempeh and tofu. The consumer's preference for soybean variety consisted of high quality of protein and oil content, high yield, and also early days to maturity as required for soybean development in tropical areas, and large seed size as required for soybean processed industry.

In Indonesia, soybeans are mostly cultivated during the dry season, hence prone to drought stress, especially at seed filling period. The drought stress at those stage will reduce the leaf water potential, reduced turgor, stomatal conductivity and other physiological activities. Furthermore, the accumulated impact will reduce the yield [12]-[16], and affect the formation process of protein and oil [17]. In fact, protein and oil are essential nutrient found in soybean seed compared to other food crops. In this study revealed that protein and oil decrease from optimal to drought environment by $0.59 \%$ and $2.82 \%$, respectively. It was also revealed that oil content apparently to be more affected by drought stress at reproductive stage compared to those protein content. A better consistency of protein than oil content also showed through a study by [7]. A study by [18] concerned to increase the oil content without reducing the 
protein content as well as the seed yield, which the choice of parental become the critical starting. A significant negative correlation between oil content with protein content was obtained by [9]. On species of Vitex, also reported by [19] that drought decreased the protein content.

The consistency of protein as well as oil content to drought was determined by cultivar, plant growth stage, the magnitude of the stress, and duration of the stress. Of 19 soybean genotypes, the protein and oil content were varied. The response among genotypes to drought stress also different. The average decrease of protein content was $0.59 \%$, lower than those of the decrease of oil content (2.82\%). The effect of drought to protein and oil content reported by [20]. They stated that drought increased the seed protein content (4.4\%), and decreased the oil content $2.9 \%$ ), and drought had little effect on the fatty acid composition of the oil. Furthermore, their study revealed that seeds from plants exposed to $35^{\circ} \mathrm{C}$ during seed fill contained 4.0 percentage points more protein and 2.6 percentage points less oil than those exposed to $29^{\circ} \mathrm{C}$ when averaged across drought stress levels.

In tropical area, such as Indonesia, soybean demand is high for processed food. On the other side, soybean is prone to drought stress. Hence, the availability of soybean variety with high protein and oil content as well as relatively less affected by drought environment, is important. Based on this study, G511H/Anjs/Anjs///Anjs-3-3 had high protein content, i.e. 42.44\% and 42.19\% in the optimal and drought environments, respectively. Soybean G511H/Anjs/Anjs-5-5 had high oil content $(19.71 \%$ and $20.08 \%$ in the optimal and drought environments, respectively) as well as G511 H/Anj//Anj///Anj////Anjs-6-8 (20.18\% and $19.43 \%$ in the optimal and drought environments, respectively). The characteristics of those three genotypes were early days to maturity, large seed size but relatively low seed yield. This is different with a result by [21], which obtained soybean genotype of Onion had high yield and high protein content under drought stress. Thus, a genetic engineering is needed to obtain soybean with high yield as well as high protein and oil content, which suitable to be developed in tropical area, such as Indonesia.

\section{Conclusion}

1) The protein and oil content were varied among soybean genotypes, and each genotype showed different response to drought stress.

2) Protein content in soybean seed was less affected by drought stress at reproductive stage compared to those oil content.

3) G511 H/Anjs/Anjs///Anjs-3-3, G511H/Anjs/Anjs-5-5 and G511 H/Anj//Anj///Anj////Anjs-6-8 could be use as genes donor to improve the protein and oil content in soybean seed.

\section{Acknowledgment}

The authors wish to thank Robert Munadi for his help during the field research in Muneng Research Station. This work was supported by the Indonesian Center of Excellence, Ministry of Research, Technology and Higher Education of the Republic of Indonesia.

\section{References}

[1] Specht, J. E., et al. (1999). Soybean yield potential-a genetic and physiological perspective. Crop Sci. 39, 1560-1570.

[2] Chowdhury, J. A., et al. (2015). Ahmed. Genotypic variations in growth, yield and yield components of soybean genotypes under drought stress conditions. Bangladesh J. Agric. Res., 40(4), pp. 537-550.

[3] Kirnak, H. M., et al. (2008). Drought stress at different reproductive stages influences growth, yield and seed composition of soybean. The Philippine Agric. Scientist, 91(3), pp. 261-268.

[4] Farooq, M., et al. (2009). Plant drought stress: effects, mechanisms and management. Agronomy for 
Sustainable Development, 29(1), 185-212.

[5] Boydak, E., et al. (2002). (2002). Seed composition of soybeans grown in the Harran Region of Turkey as affected by row spacing and irrigation. J. of Agric. and Food Chem., 50, 4718-4720.

[6] Hwang, E., et al. (2014). A genome-wide association study of seed protein and oil content in soybean. BMC Genomics, 15, 1-12.

[7] Piper, E. L., \& Boote, K. J. (1999). Temperature and cultivar effects on soybean seed oil and protein concentrations. JAOCS, 76, 1233-1241.

[8] Yin, X., \& Vyn, T. (2005). Relationships of isoflavone, oil and protein in seed with yield in soybean. Agron. J., 97, 1314-1321.

[9] Mao, T., et al. (2013). Identification of quantitative trait loci underlying seed protein and oil contents of soybean across multi-genetic backgrounds and environments. Plant Breeding, 132, 630-641.

[10] Candogan, B. N., \& Yazgan, S. Yield and quality response of soybean to full and deficit irrigation at different growth stages under sub-humid climatic conditions. J. of Agricultural Sci., 22, 129-144, 2016.

[11] Maleki, A., et al. Physiological performance of soybean cultivars under drought stress. Bull. Env. Pharmacol. Life Sci., 2, 38-44, 2013.

[12] Dennis, B. E., \& Bruening, W. P. (2000). Potential of early maturing soybean cultivars in late plantings. Agron. J., 92, 532-537.

[13] Nakasathien, S., et al. (2000). Regulation of seed protein concentration in soybean by supra-optimal nitrogen supply. Crop Sci., 40, 1277-1284.

[14] Board, J. E. (2002). A regression model to predict soybean cultivar yield performance soybean cultivar yield performance at late planting dates. Agronomy. J., 94, 483-492.

[15] Dogan, E. H., et al. (2007). Deficit irrigations during soybean reproductive stages and CROPGRO-soybean simulations under semi-arid climatic conditions. Field Crops Research, 103, 154-159.

[16] Nasirkhan, M., et al. (2007). Salinity induced changes in growth, enzyme activities, photosynthesis, proline accumulation and yield in linseed genotypes. World J. Agric. Sci., 3, 685-695.

[17] Ghassemi-Golezani, K., \& Farshbaf-Jafari, S. (2012). Influence of water deficit on oil and protein accumulation in soybean grains. International J. of. Plant, Animal and Environ. Sci., 2, 46-52.

[18] Eskandari, M., et al. (2013). Genetic control of soybean seed oil: II. QTL and genes that increase oil concentration without decreasing protein or with increased seed yield. Theor. Appl. Genet., 126, 1677-1687.

[19] John, D. B. A., et al. (2011). Drought stress and its impact on protein in three species of Vitex. Journal of Stress Physiology \& Biochemistry, 7, 152-158.

[20] Dornbos, D. L., \& Mullen, R. E. (1991). Soybean seed protein and oil contents and fatty acid composition adjustments by drought and temperature. Journal of the American Oil Chemists Society, 69, 228-231.

[21] Vahdi, N., et al. (2015). Effect of drought stress on seed yield, oil and protein of soybean (Glycine max L.) different cultivars. Journal of Oil Plants Production, 2, 98-115.

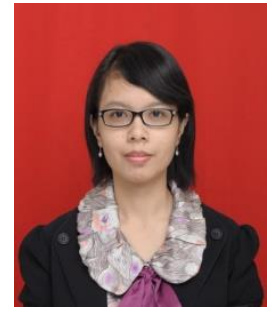

Ayda Krisnawati was born in Pacitan, 11 June 1981. Master Degree of Plant Breeding from Gadjah Mada University (Yogyakarta, Indonesia) in 2013.

She works as soybean breeder in Indonesian Legumes and Tuber Crops Research Institute (ILETRI), under Indonesian Agency for Agricultural Research and Development, Ministry of Agriculture Republic of Indonesia, since 2005. Now holding position as Junior Researcher. Papers that have been produced up to now more than 30 manuscripts on the 
topic of soybean breeding, sweet potato breeding, and legumes and tuber germplasm.

Ayda Krisnawati, S.P., M.Sc. had opportunity to do internship about Soybean Breeding and Germplasm Management for 2 weeks at the National Institutes of Agrobiological Sciences (NIAS), Tsukuba, Japan. Whereas in 2010 got a scholarship from NFP (The Netherlands Fellowship Programme) of the Netherlands Government to follow shortcourse for 3 (three) weeks with the theme "Contemporary approaches to genetic resources conservation and use" in Wageningen, the Netherlands.

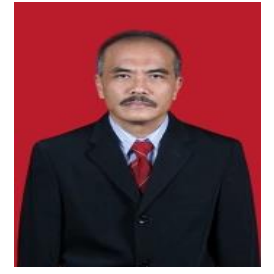

M. Muchlish Adie was born in Sampang on May 31, 1957. He got the doctoral degree of plant breeding from Brawijaya University (Malang, Indonesia) in 2008.

He works as soybean breeder in Indonesian Legumes and Tuber Crops Research Institute (ILETRI), under Indonesian Agency for Agricultural Research and Development, Ministry of Agriculture Republic of Indonesia, since 1977. Holding a position as Young Breeding Research Assistant in 1991, and since 2003 holding a position as Associate Researcher Breeding. Has released 35 soybean varieties with more than 100 publications.

Dr. M. Muchlish Adie, M.S got a chance to follow the Visiting Scientist Program, sponsored by the Japan International Research Center for Agricultural Sciences (JIRCAS) in 1996. Year of 2002 was awarded as Outstanding Researcher from Indonesian Government. Year of 2013 received 'Adhikarya Pangan Nusantara' Award. The awards are given to personal or group as an appreciation and acknowledgement of achievement, hard work, and consistency in supporting the food security in Indonesia. 